\title{
パワーエレクトロニクスの実装技術
}

\section{Packaging Technology for Power Electronics}

\author{
加柴良裕* \\ Yoshihiro KASHIBA
}

(Received 9 July 2020, Accepted 17 August 2020)

Key Words: IGBT, SiC, Power Modules, Assembly, Inverter

\section{1. はじめに}

冷蔵庫、エアコン、ハイブリッドカー、太陽光発電等、 パワーエレクトロニクス (以降、パワエレ) 技術を利用した 製品は我々の日常生活に深く入り込んでいる。また、この ようなパワエレ製品は家庭だけでなくオフィスから産業、 インフラ等、幅広い分野で適用拡大が進んでいる。

パワエレとはパワーデバイスをスイッチングすることに よって電気を制御して、モータを駆動したり電力を変換し たりする技術であり、世界の電力消費を抑え、地球温暖化 防止のためにも欠くことのできない技術となっている。と くに近年では、 $\mathrm{Si}$ 半導体の物性を大幅に凌駕できる化合物 半導体の実用化開発が推進されており、革新的な技術とし て期待されるとともに、その適用が拡がっている。これら パワエレ製品を支えている基本技術に回路設計や電気制御 技術等があるが、小型・高機能化が進むにつれ重要視され てきたのがパワエレ実装技術である。

本稿では、これからの社会にとってますます重要となっ ていくパワエレの実装技術に関して現状とその動向につい て述べてみたい。

\section{2. 実装の階層}

エレクトロニクス製品における実装はその形態から 4 つ の階層に分類することができる ${ }^{1)}$ 。すなわち、階層 I は半導 体デバイス内部の相互接合・接続のための配線技術、階層 II は半導体デバイスや電子部品のアセンブリ技術、階層 III はプリント基板への主にはんだ付による実装技術、階層 IV はプリント基板間の配線や筐体組み立て技術である。

パワエレ実装においても実装の階層は同様にとらえるこ とができ、Fig. 1 に示すように、階層 I から階層 IV に分類 することができる。とくにパワエレ製品では大電流や高電 圧を取り扱うため、放熱技術や絶縁技術およびそれに関連 する技術が実装にとってより重要となる。
階層 I のパワーデバイスの上下面電極にはメタライズ層 が形成されており、高温下での安定性が要求される。また、 上下面電極とも階層 II でのアセンブリ安定性が必要となり、 上面は $\mathrm{Al}$ 、下面は $\mathrm{Ni} / \mathrm{Au}$ を用いることが多い。デバイス機 能に対して、市場から最も要求される性能は動作時に発生 する熱を減らすこと、すなわち電力損失の低減である。パ ワーデバイスは数 $\mathrm{A}$ から数百 $\mathrm{A}$ 程度までの電流を制御する が、通電時や電流のオンオフ（スイッチング）時に電気エ ネルギの一部が熱エネルギに変換されてしまうことが避け られず、この電力損失を下げることが大きな課題となって いる。1980 年代のパワーデバイスであるバイポーラトラン ジスタの動作時の電力損失に対して、IGBT (Insulated Gate Bipolar Transistor) は世代を重ねる毎に電力損失の低減を実 現してきた2)。当初のセル構造はプレーナー構造であった が、トレンチ構造が開発され、電力損失を大幅に低減する ことによってデバイスを小型化した。更に、その後、トレ

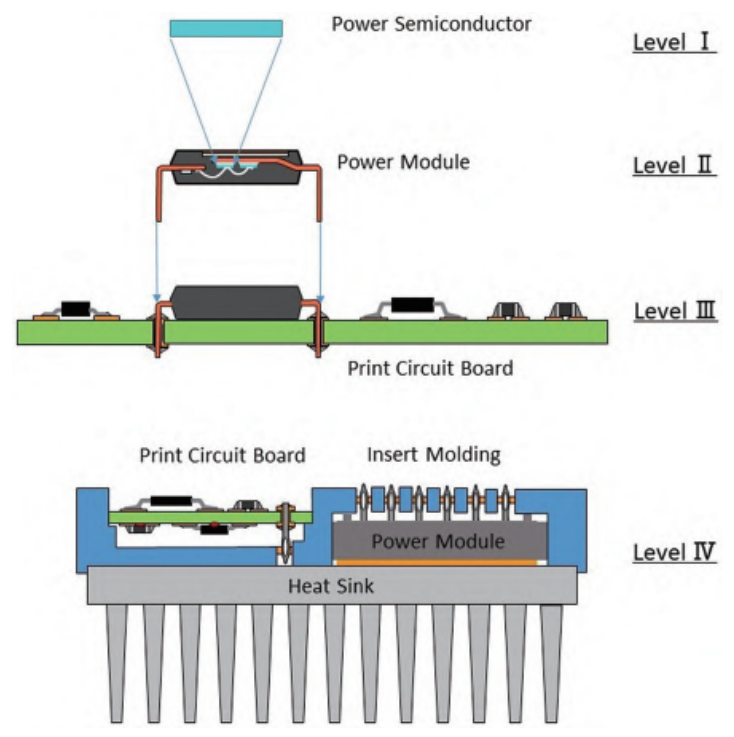

Fig. 1 Packaging level (Level I Level IV) of power electronics.

*大阪大学大学院工学研究科（

Graduate School of Engineering, Osaka University（2-1 Yamadaoka, Suita, Osaka 565-0871, Japan) 
ンチ間隔の狭ピッチ化及び薄ウエハ化が行われた。このよ うな構造やプロセスの改善によってデバイス性能は大幅に 向上している。さらに近年は、 $\mathrm{SiC}$ など化合物半導体の開 発が精力的に進められている。この化合物半導体を用いる ことによって電力損失は一気に $1 / 4$ から $1 / 10$ になるな、 実用化が始まっている。この電力損失の低減は、次に述べ る階層 II となるパワーデバイスのパッケージの小型化に直 接影響する。

階層 II であるパッケージのアセンブリはその形態から、 1 個のパワーデバイスをパッケージに収めたディスクリー トと複数のパワーデバイスをパッケージに収めたモジュー ルに分けられる。電源等の比較的小容量の電力制御には ディスクリートが用いられるが、産業用のインバータやハ イブリッドカーにはモジュールが用いられる。パワーデバ イスの動作温度は上限が決まっているため、電力損失が低 減したことによって、デバイスの温度上昇を抑えることが 可能となり、モジュール内のデバイスを高密度に実装する こと、すなわちパッケージの小型化が実現される。

階層 III はパワーモジュールをプリント基板に実装する階 層である。汎用のプリント基板への実装は電流容量や放熱 性の課題のためエアコン等の比較的小容量のパワエレ機器 に用いられる。熱容量や放熱との関係上パワーモジュール は DIP (Dual Inline Package) などの挿入部品が多く、実装時 においても熱容量が大きい場合には他の制御用部品とは別 に局所フローソルダリングが行われる。

階層 IV はモジュールとモータや制御回路基板を相互に接 続し、それぞれの機能を有する部材をシステム化する階層 である。パワエレ機器においては放熱部材であるヒートシ ンクを筐体の一部として使う実装形態、銅配線板を射出成 型筐体に埋め込んで回路を形成した 3 次元実装の形態、モー タとインバータを一体化した実装形態等、パワエレ機器の 小型化ニーズに対応して多くの実装形態が開発されている。

以下、階層 II から IV について詳説する。

\section{3. パッケージのアセンブリ技術（階層 II）}

ディスクリートパッケージとパワーモジュールのパッ ケージとの最大の違いは絶縁構造にある。パワーモジュー ルは複数のデバイスによる電気回路の形成、パッケージ外 部との電気的絶縁、デバイス動作時に発生する熱の放散と いう複数の機能を有しているため階層 III における実装が簡 便となり、多くの設計者から支持を得た。

パワーモジュールの構造はそのアセンブリ形態からさら に Fig. 2 に示すように、モールド構造とケース構造に分け ることができる。モールド構造はリードフレーム上に複数 のパワーデバイスを搭載して回路を形成した後、トランス ファーモールドした構造である。ディスクリートと類似の アセンブリ工程を用いることができ、大量生産に適してい るうえ、放熱性能を確保しつつ絶縁機能も有する構造に大 きな特徴がある。絶縁を確保する構造としては、モールド
時の樹脂を絶縁材として用いる方法、シート状の絶縁部材 を用いる方法、セラミック基板を用いる方法があり、放熱 性能によって適宜選択される。モールドタイプの構造は比 較的小電流の主に家電用途に用いられるが、この構造は 10 年間で約 $1 / 4$ のサイズとなっている。これはデバイスの電 力損失が $1 / 2$ になるとともに、パッケージの熱抵抗が $1 / 2$ となったためである。熱抵抗低減には高熱伝導樹脂やセラ ミック基板の採用等が有効であり、さらに大容量化が進ん でいる。一方、ゲルなどで封止したケース構造は大電流や 高電圧の主に産業用途に用いられる。樹脂絶縁された金属 基板やセラミック基板上にパワーデバイスを複数搭載して 回路を形成し、その後樹脂で封止した構造である。この樹 脂封止型パワーモジュールは小型化、大容量化、高放熱化 の流れがある。この中でも、高放熱化の動きは構造の大幅 な変更を伴って進んでおり、Fig. 3 に示すような、両面冷 却 $^{3)}$ 、直接水冷 ${ }^{4)}$ 、両面直接水冷 ${ }^{5)}$ 等の新構造が開発されて

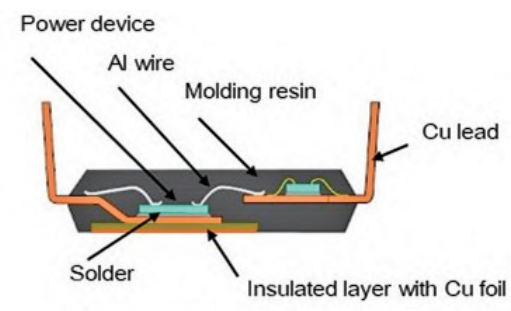

Resin Molded Structure

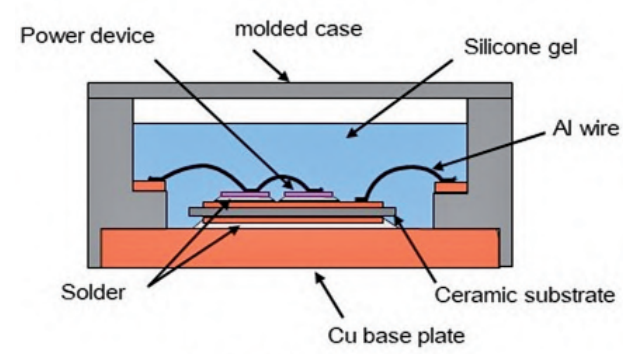

Case Structure

Fig. 2 Different 2 types of power module structure.

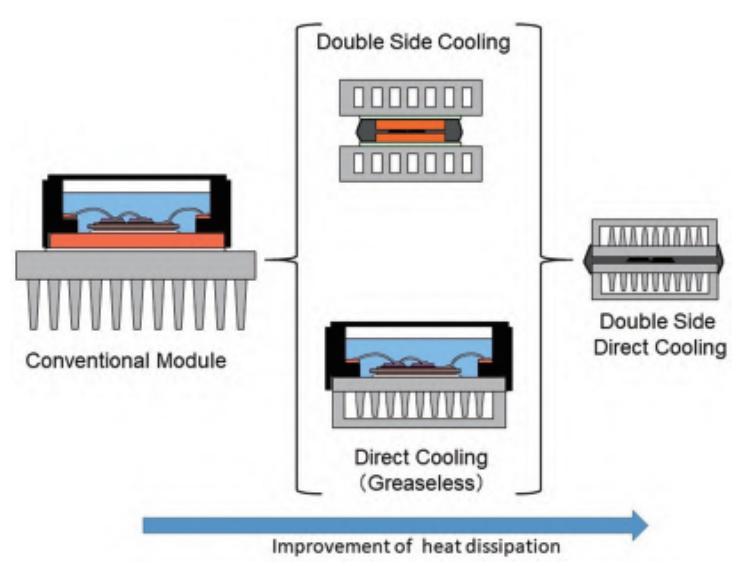

Fig. 3 Improvement of heat dissipation by power module structure development. 
いる。とくに、両面直接水冷モジュールは、デバイスを両 面から冷却しつつモジュールとヒートシンクを接続するた めの低熱伝導率のグリースを排除することができるため、 大幅な放熱特性改善が可能となる。

パワーデバイスの低損失化やパッケージの高放熱化に 伴ってパワーモジュールの電力密度の向上は年々進んでい る。さらに、損失を大幅低減できる $\mathrm{SiC}$ デバイスの開発 が進んでおり、鉄道車両用のモジュールを適用することに よって、高効率化・小型化が実現されている ${ }^{6)}$ 。

パワーモジュールの動向は小型化等の流れだけでなく、 より厳しい環境下、たとえば高温となるエンジンルーム内 での使用や長寿命化等の流れがあるため、耐熱・信頼性設 計が重要となっている。パワーモジュールでは、デバイ スの動作に伴う熱によってパワーデバイス近傍やパワーモ ジュール全体の温度が変化することは避けられない。しか し、パワーモジュールは、電気回路形成、放熱、電気絶縁 の機能を発揮するため、それぞれの機能を有する材料を複 合化した構造をとっている。このような構造においては熱 疲労破壊に対する信頼性設計が大きな課題となる。すなわ ち、各部材の熱澎張係数が大きく異なるため、それぞれを 接合する材料や積層構造の設計が重要である。また、 $200^{\circ} \mathrm{C}$ 以上の高温下での使用を考えた場合、ケースやゲル等の有 機材料やはんだ材料自身が劣化しないように寿命設計する 必要があり、材料とくに接合材料の高耐熱化が検討されて いる。

まず、セラミックスと $\mathrm{Cu}$ 導体を接合して製造されるセ ラミック基板は DBC (Direct Bonded Copper) 基板と称され、 パワーモジュールにとって不可欠の部材となっている。セ ラミック基材には高熱伝導性の $\mathrm{AlN}$ や高強度の $\mathrm{Si}_{3} \mathrm{~N}_{4}$ が採 用され、産業用や車載用等それぞれの製品要求に対応した $\mathrm{DBC}$ 基板が実用化されている。パワーモジュールの品質や 機能にとってこの DBC 基板のセラミック・金属接合部に は大きな熱応力が発生するため、脆性なセラミックが破壞 しないようセラミック材料物性の改善が図られている。

パワーモジュールの心臓部にあたるデバイス上下の接合 技術は、それぞれワイヤボンディングとダイボンディング である。

ワイヤボンディングの材料は直径 $400 \mu \mathrm{m}$ 程度のアルミ ニウムが多く用いられる。ワイヤボンド部は超音波接合に よってパワーデバイス上の $\mathrm{Al}$ 電極と $\mathrm{Al}$ ワイヤを直接金属 接合されているが、パワーデバイスの動作パターンに対応 して比較的頻繁に温度変化が生じる。この環境下で使用し 続けると最終的にはワイヤとデバイスメタライズの界面近 傍で破壊するため、高品質の接合ができるプロセスや長寿 命が可能となるワイヤ材料やデバイスのメタライズ材料が

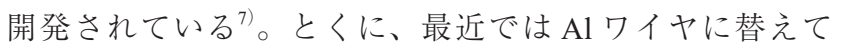
$\mathrm{Cu}$ ワイヤを用いることによって大幅な長寿命化を図る方法 も開発されている ${ }^{8)}$ 。なお、 $\mathrm{Cu}$ は $\mathrm{Al}$ に比べると低熱膨張・ 高電気伝導度である、というメリットを有するが、剛性が
高いためデバイスのダメージを防止する必要がある。また、

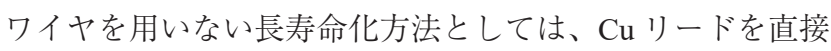
デバイス表面のメタライズ層にはんだ付する構造がとられ ることもある9 。このような配線構造とモールド樹脂によ る封止構造を合わせて適用することによって、寿命はゲル 封止のワイヤボンディング構造に比べると 10 倍程度まで伸 びる。

デバイス下の接合、いわゆるダイボンド部には基本的に はんだ付が用いられる。デバイスと $\mathrm{DBC}$ 基板の熱膨張差 によって熱応力破壊が発生することがあるが、その寿命は、 はんだのひずみ量と強い相関があることが知られている。 亀裂が進展した場合はパワーデバイスからの放熱経路が狭 められる結果、パワーデバイスの熱破壊が生じるため、こ れを防止できるよう寿命設計を行う必要がある。また、は んだ接合部の耐熱性・信頼性を向上するためには、はんだ 材料の機械的特性を改善することが有効でとされている7)。 さらに、信頼性向上のためにはエポキシ樹脂封止すること も有効となる。この構造では、はんだのひずみ量を比較的 線膨張係数が大きいエポキシ樹脂も含めて構造体を形成す るため、はんだのひずみ量低減すなわち信頼性の向上が実 現できる9)。

$\mathrm{SiC}$ デバイスなど高温で用いることができるデバイス対 応のダイボンド技術としては、Ag 焼結接合等はんだ材料 を用いない接合技術が開発されている ${ }^{10-14)}$ 。 $\mathrm{Ag}$ 焼結接合の 特徵としては $250^{\circ} \mathrm{C}$ 程度の低温で接合した接合部は $\mathrm{Ag} の$ 融点までは再溶融しないことであり、耐熱性・信頼性の向 上が期待できる。Fig. 4 にナノ $\mathrm{Ag}$ 粒子を用いた接合過程 を模式的に示す。まず有機膜で保護されたナノ $\mathrm{Ag}$ 粒子が 加熱によって有機膜が分解され、次にさらに加熱下で保持 することによってナノ $\mathrm{Ag}$ 粒子の焼結が進行する。 $300^{\circ} \mathrm{C}$ 以 下の接合プロセスであり、とくに近年では無加圧でも安定
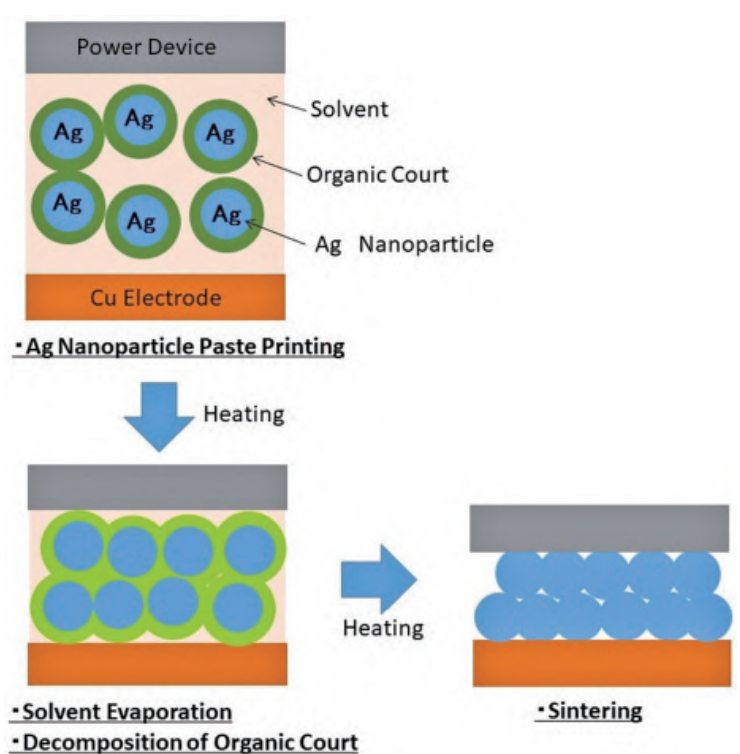

Fig. 4 Schematic of nano-Ag sintering process. 
した接合が可能となっているため、はんだ付の代替技術と して用いることができる。20 nmの Ag 粒子を用いて温度 $260^{\circ} \mathrm{C}$ 、加圧力 $30 \mathrm{MPa}$ 、時間 $90 \mathrm{~s}$ の条件下で接合した接合 部を Fig. 5 に示す ${ }^{12)}$ 。大きな欠陥は見られず、 $1 \mu \mathrm{m}$ 以下の 小さな空孔が接合部全体に対して分散していることがわか る。この接合部は最高温度 $200^{\circ} \mathrm{C}$ の繰り返し温度サイクル 6000 回においても焼結接合部に大きな劣化は見られず、は んだ材料に対して大幅に耐熱性および信頼性が向上するこ とが確認されている。以上のようなはんだ代替材料・プロ

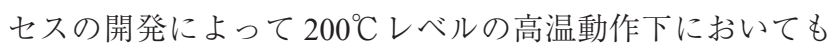
放熱経路として重要なダイボンド部の信頼性が確保できる ことが明らかとなっている。

また、環境温度の变化等比較的長時間の温度変化に対し て劣化が懸念される $\mathrm{DBC}$ 基板とヒートシンクの接合材を はんだ付に替えて直接ろう付する構造も耐熱性向上や信頼 性向上にとって有効な手段となる。

\section{4. プリント基板の実装技術（階層 III）および機器実装技術 (階層 $\mathrm{N}$ )}

プリント基板への実装は冷蔵庫やエアコン等の家庭用イ ンバータに主に用いられる。ただ、パワーデバイスの電力 損失が低減した結果、比較的小容量であったモールド樹脂 封止型パワーモジュールにおいても50 A を超える大容量 化が進んでおり、それを実装するプリント基板の電流容量 が問題となってくる。すなわち、汎用プリント基板の銅箔 回路パターンに大電流を通電することによるジュール発 熱の問題である。例えば銅箔厚さ $35 \mu \mathrm{m}$ 、幅 $20 \mathrm{~mm}$ 、長さ $100 \mathrm{~mm}$ の回路パターンの抵抗值は $2.4 \mathrm{~m} \Omega$ であるが、 $50 \mathrm{~A}$ の電流を流すとその箇所の発熱量は $6 \mathrm{~W}$ となってしまい、 放熱経路が確保されないと熱的に成立しない。そこで、プ リント基板に通電・放熱のための補助部材を利用するほか、 内層銅䇴を放熱経路に利用することなどによって $100 \mathrm{~A}$ 程 度の電流を汎用のプリント基板を用いて実装することが可 能となっている ${ }^{15)}$ 。さらに、プリント基板を金属筐体と絶 縁熱伝導材料を介して接触させることによって、銅箔回路 パターンの温度上昇を大幅に低減することも可能となって いる。

一方、大型のパワーモジュールをプリント基板にはんだ 実装する場合、パワーモジュールの熱容量が大きいため基

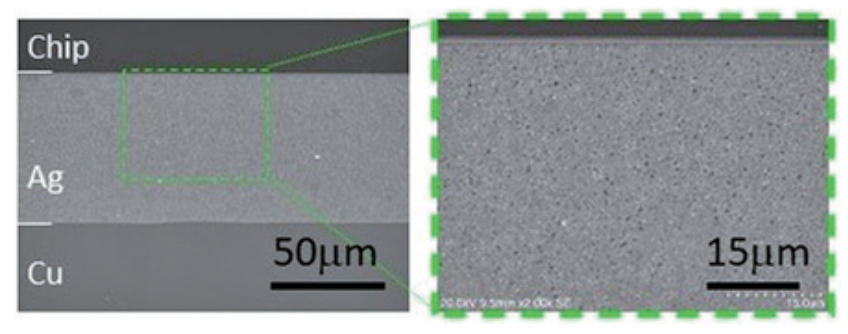

Fig. 5 Cross section of sintered joint at $260^{\circ} \mathrm{C}$ for $90 \mathrm{~s}$ with bonding pressure of $30 \mathrm{MPa}$.
板や周辺部品への熱ダメージ回避が容易ではなく、フラッ クス洗浄も環境問題の関係上から用いたくないという要求 がある。これに対して、はんだ付に代わるプレスフィッ ト技術が欧州を中心に開発注力されている。このプレス フィット技術は信号線の機械的接続技術として利用されて きたが、近年パワーモジュールの電力端子にも適用展開が 進んでいる ${ }^{16-18)}$ 。課題としては大電流通電による接続部の 発熱とモジュールとプリント基板の線膨張係数差による動 作時の変位による接触状態の変化である。これに対して、 接続部の解析が行われ、Fig. 6 に示すように、プリント基 板のスルーホールの $\mathrm{Cu}$ めっとプレスフィット端子の $\mathrm{Sn}$ めっきの接触界面には数 $\mathrm{nm}$ から数十 $\mathrm{nm}$ の結晶粒からな る混合層が形成されていることが明らかとなった。また、 この接続部は、 $50 \mathrm{~A}$ 通電時においてもその温度上昇は許容 内であり、 $-40 \sim 85^{\circ} \mathrm{C} 、 600$ サイクルの温度サイクル後に おいても安定的な接続が実現できていることが確認され、 実用的な接続技術であると判断できる。

また、パワエレ機器の小型化の一つの方策として、モー タにインバータ機能を内蔵したインバータ一体型モータの 検討がなされている。モータとインバータの組み合わせに おいて、インバータを円盤状に実装し、モータと一体化し たシステム化構造においては、体積は $20 \%$ 減、質量は $31 \%$ 軽量化が達成されている ${ }^{19)}$ 。

\section{5. おわりに}

本解説では、パワエレ実装をその実装レベルに対応して 4 階層に分類し、その特徴および最近の技術動向を述べた。 パワエレ製品は家庭からインフラまで様々な分野で用途拡 大が進んでいる。とくに日本がリードしてきた省エネ技術 は地球温暖化防止には不可欠の技術であり、パワエレの電 気回路・制御技術とそれを引き出すパワエレ実装技術を総 合的に推進していくことが必要である。

この解説を通してパワエレ実装に関係する研究・開発者 が増加し、将来の地球に低炭素社会の構築という大きな財 産を残していただければ幸いである。

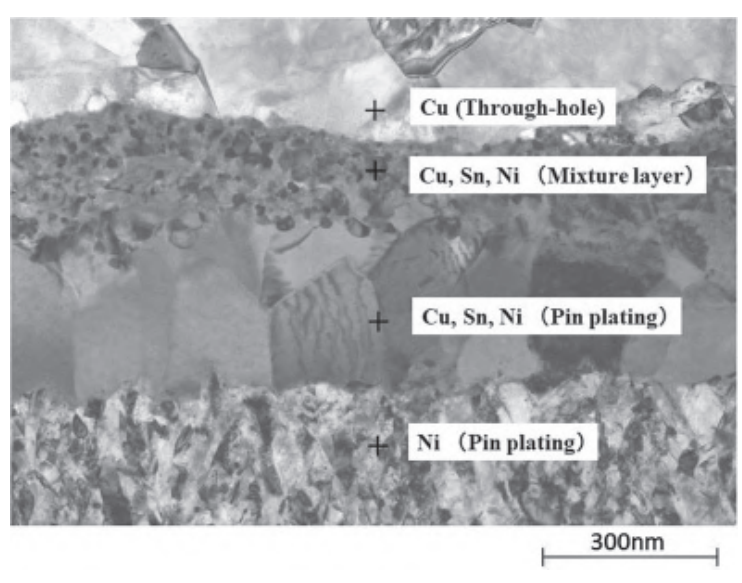

Fig. 6 STEM image of contact pin and through-hole interface. 


\section{参考文献}

1）（社）溶接学会マイクロ接合研究委員会編：“マイクロ接合技 術 (第 1 編)”, 溶接学会, (1987), 259.

2）西原秀典, 松岡徹 : “パワーモジュールの最新動向と展望” 三 菱電機技報, 94-3 (2020), 148-152.

3）坂本善次，平野尚彦：“車載用パワーエレクトロニクス製品の 紐解きと，両面放熱パワーモジュールの実装技術”，溶接学会 誌, 80-4 (2011), 22-26.

4）吉松直樹, 碓井修, 井本裕児, 石山祐介：“自動車用パワー半 導体モジュール J1 シリーズのパッケージ技術”, 三菱電機技報, 88-5 (2014), 321-324.

5）木村隆志, 斎藤隆一, 久保謙二, 中津欣也, 石川秀明, 佐々木要 “ハイブリッド電気自動車向け高電力密度インバータ” 日立評 論, 95-11 (2012), 752-757.

6）菅原徹大, 山下良範, 中嶋幸夫：“ $\mathrm{SiC}$ パワーモジュールの主 回路素子への適用技術”, 三菱電機技報, 90-9 (2016), 517-520.

7）両角朗, 西村芳孝, 池田良成, 望月英二, 高橋良和: “パワー モジュールに抢ける高耐熱パッケージ技術”，エレクトロニク 又実装学会誌, 17-6 (2014), 464-468.

8) K. Guth, N. Heuck, CH. Stahlhut, A. Ciliox, N. Oeschler, L. Boewer, S. Tophinke, D. Bolowski, R. Speckels, CH. Kersting, S. Krasel and G. Strotmann: "End-of-life investigation on the .XT interconnect technology", PCIM Europe 2015

9）中島泰, 須藤進吾, 多田和弘, 鹿野武敏, 佐々木太志, 加柴 良裕：“リード接合を用いた大容量樹脂封止型パワーモジュー ル”, 第 11 回「エレクロトニクスにおけるマイクロ接合・実 装技術」シンポジウム，(2005), 433-436.

10）廣瀬明夫：“銀ナノ粒子抢よび酸化銀粒子を用いた低温焼結接 合”，溶接学会誌， 80-8 (2011), 702-708.

11) H. Tatsumi, S. Kumada, A. Fukuda, H. Yamaguchi and Y. Kashiba: "Impact of Metallurgical and Mechanical Properties of Sintered
Silver Joints on Die-Attach Reliability of High-Temperature Power Modules", J of Microelectronics and Electronic Packaging, 13-3 (2016), 121-127.

12) Z. Shen, A. Reiderman and C. Anude: "Pressure-less AgNP Sintering for High-power MCM Assembly for Extreme Environment Applications", 48th Annual International Symposium on Microelectronics, (2015), 342-348.

13）木村良，苅谷義治，水村宜司，佐々木幸司：“Ag 十八粒子焼 結隊の疲労亀裂進展速度に及ほすす焼結温度の影響”，第 24 回 「エレクロトニクスに抄けるマイクロ接合・実装技術」シンポ ジウム, (2018), 211-216.

14）山際大貴, 松田朋已, 巽裕章, 佐野智一, 加柴良裕, 古澤秀樹, 佐藤賢次, 廣瀬明夫：“サブミクロン銅粒子を用いた無加圧接 合に扔ける焼結プロセスの検討”，第 26 回「エレクロトニク スに打けるマイクロ接合・実装技術」シンポジウム，(2020）, 323-328.

15）白形雄二, 藤井健太, 中島浩二, 佐藤翔太, 熊谷隆: “プリン ト基板を活用したパワーエレクトロニクス機器の低コスト実 装技術”，三菱電機技報，91-7 (2017), 401-404.

16) G.J. Riedel: "Current capability of press-fit contacts of IGBT modules", 6h IET International Conference on Power Electronics, Mechanism and Devices (2012), 1-6.

17）江草稔, 石橋英俊, 大坪義貴, 菊池正雄, 加柴良裕：“大電流 用プレスフィット部における界面状態と接触安定性に関する 検討”, スマートプロセス学会誌, 7-4 (2018), 139-145.

18) M. Thoben, I. Graf and R. Tschirbs: "Press-fit Technology, a Solderless Method for Mounting Power Modules”, PCIM 2005.

19）宇津野良, 松井康平：“インバー夕一体型モー夕”, 富士電機 技報, 88-1（2015）, 41-45.

\section{代表者メールアドレス}

加柴良裕 kashiba@mapse.eng.osaka-u.ac.jp 